sciendo

\title{
Krzysztof Zowada
}

(iD) https://orcid.org/0000-0002-5848-0583

Department of Business Logistics

Faculty of Management

University of Economics in Katowice,

Katowice, Poland

krzysztof.zowada@uekat.pl

\section{Going green in logistics: The case of small and medium-sized enterprises in Poland}

Accepted by Editor Ewa Ziemba | Received: October 13, 2020 | Revised: January 10, 2021; February 2, 2021; February 11, 2021 | Accepted: February 15, 2021 | Published: March 4, 2021.

(C) 2021 Author(s). This article is licensed under the Creative Commons Attribution-NonCommercial 4.0 license (https://creativecommons.org/licenses/by-nc/4.0/)

\begin{abstract}
Aim/purpose - The aim of the paper is to identify the features of 'green' small and medium-sized enterprises operating in Poland.

Design/methodology/approach - The paper is based on a quantitative approach and a group of 200 small and medium-sized enterprises operating in Poland were examined. The classification tree method was used to analyze the data gathered.

Findings - The 'green' small and medium-sized enterprises operating in Poland were characterized and their important features were identified, e.g., belonging to the TFL (Transport Forwarding Logistics) sector and a direct relationship with the supply chain leader. In the case of enterprises from the TFL sector, their area of activity is a natural environment for the development of 'green logistics' practices. In turn, the supply chain leader usually pushes for specific solutions aimed at achieving the assumed goals, including environmental goals.

Research implications/limitations - The research results enable the identification process of small and medium-sized enterprises interested in implementing the 'green logistics' concept and, consequently, their support. Nevertheless, small and medium-sized enterprises operating in Poland were the only examined, thus the research findings cannot be generalized for other countries. However, the paper could be a starting point for comparative analyses on an international scale.

Originality/value/contribution - The development of 'green logistics' among small and medium-sized enterprises in Poland is still not recognized by researchers. The paper is a valuable addition to this research gap.
\end{abstract}


Keywords: green logistics, SME, classification tree.

JEL Classification: L21, M20, Q50.

\section{Introduction}

The development of civilization is a widely accepted and desirable process. This causes individuals to use more and more advanced technologies related, for example, to the transfer and exchange of information. As a consequence, apart from the undeniable benefits, the effect of this development is a growing demand for natural resources and a growing negative impact on the environment (Chunguang, Xiaojuan, Kexi, \& Pan, 2008; Tamulis, Guzavičius, \& Žalgirytè, 2012). Phenomena related to environmental pollution affect not only the human environment, but above all cause a deterioration in human health. Importantly, the scale of these threats does not only apply to individual local communities, but has a global dimension. Environmental protection is therefore one of the most important challenges facing governments and societies around the world today (Dogaru, 2013). Numerous institutions that indicate the need to reduce the negative impact of people on the natural environment include many international organizations (such as the UN, EU, WTO, World Bank) individual countries and non-governmental organizations (Greenpeace, WWF) (European Commission, 2020; Greenpeace International, 2020; UN, 2020; World Bank, 2020; WTO, 2020; WWF, 2020).

The needs related to natural environment protection have also become the main prerequisite for finding new management concepts enabling the development of solutions which are environmentally responsible and economically effective at the same time (Ambec \& Lanoie, 2008; Chang \& Qin, 2008). One of the concepts which can be an answer to the requirements related to environment protection is the 'green logistics' concept. According to Jedliński (2010), 'green logistics' is integrated management of all activities required to move a product along the supply chain to meet the expectations of customers at minimum global cost including the external costs also related to, among others, climate change, air pollution, noise, vibration, and accidents. It is generally accepted that it is primarily designed to measure and reduce the negative impact of the overall logistics activities on the ecology, and the parameterization of the effects increases the state of awareness of the consequences of the actions taken, and at the same time gives the possibility of indicating potential areas for optimization. In the opinion of McKinnon, Browne, Piecyk, \& Whiteing (2015), 'green logistics' is a form of logistics which is expected to not only be environmentally but often socially friendly and economically functional. According to the author, 'green logistics' is a concept for managing the flow of material and the accom- 
panying flow of information, starting at the design stage, in such a way that the ecological, social and economic goals of the organization can be achieved. It can therefore be said that this is a proposal to solve one of the important problems facing enterprises in the 21 st century.

The literature review shows that publications referring to the development of 'green logistics' have so far focused on the processes of implementation and development of 'green logistics' in large enterprises or entire supply chains (Abdullah, Sarfraz, Qun, \& Javaid, 2018; Lai \& Wong, 2012; Lo, 2014; McKinnon et al., 2015; Zhang, Thompson, Bao, \& Jiang, 2014). In other words, the reviewed research studies did not take into account the specific nature of the SME (small and medium-sized enterprises) sector, which is a very important factor considering its diversity and, most of all, its high significance and size in the national economy ${ }^{1}$. As a consequence, a research gap related to the development of 'green logistics' among small and medium-sized enterprises was identified.

In Poland, despite few scientific studies on green logistics, many examples of practical applications of this concept can be observed. An increasing number of owners and managers of small and medium-sized enterprises, when making decisions about logistics processes, take into account not only the economic criteria, but also ecological ones (for example, choosing means of transport that are less harmful to the environment or using reusable packaging) (Zowada, 2020). Therefore, it is worth to identify the features of small and medium-sized enterprises that have become the most involved in the processes of implementing the 'green logistics' concept (the so-called 'green' enterprises). Consequently, the aim of the paper is to identify the features of 'green' small and medium-sized enterprises operating in Poland. Achieving the assumed aim will facilitate the identification process and hence support for small and medium-sized enterprises interested in implementing the 'green logistics' concept.

The paper is organized in the following way. The literature review focuses on the topic related to the development of 'green logistics' in business operations in particular. The third section concerns the methodology used for this study. The fourth, empirical section presents the research findings and discussion, focusing on the studied 'green' enterprises. The conclusions are drawn in the final section, where the research contribution as well the implications for research and practice are highlighted and new exploration topics for further research are suggested.

1 A similar view in the context of green solutions in SMEs is expressed by: Hove-Sibanda, Sibanda, \& Mukarumbwa (2018), Ivanova (2020), Mala \& Musova (2015). 


\section{Literature review}

In response to emerging expectations of various stakeholder groups, managers adopt specific attitudes towards the challenges of a pro-ecological approach to business management (van Hoek, 1999; Lau, 2011; Sarkis, 2012). In general terms, two extreme orientations are indicated: reactive and proactive. They are characterized by different levels of ecological awareness of managers (van Hoek, 1999; Lau, 2011; Sarkis, 2012). In a reactive attitude, only actions that are forced on enterprises are undertaken, usually (but not only) as a consequence of introducing specific legislative solutions. In this case, managers respond to specific problems without trying to take any preventive action. In turn, all measures taken to protect the environment are considered primarily in the category of unnecessary costs (Jabbour, Jabbour, Govindan, Kannan, \& Fernandes Arantes, 2014). In the situation of proactive actions, managers with a high level of ecological awareness make decisions in accordance with a previously developed environmental policy, thus anticipating the emergence of any problems arising from non-compliance with the requirements of various stakeholder groups. The implemented actions are therefore not considered only in the category of incurred costs, but above all are measurable benefits. In a situation where managers adopt proactive attitudes, the enterprises they manage can be (Testa \& Iraldo, 2010; Vachon \& Klassen, 2007): reputation-led - an enterprise focused on achieving the image of a company responsible for the environment; efficiency-led - an enterprise oriented towards achieving high efficiency due to lowering unit cost and, as a consequence, providing a price competitive product; or innovation-led - an enterprise oriented towards innovation, seen as one of the innovation leaders in order to strengthen its position against competitors, creating a kind of gap in relation to them in terms of know-how.

In relation to the presented managers' attitudes towards implementing proecological solutions in management practice, Murphy, Poist, \& Braunschweig (1995) classified enterprises according to their attitude to environmental protection during the implementation of logistics processes. In the first group, they mention progressive companies in which logistics plays a very important role in formulating environmental strategies. Enterprises that belong to this group use a wide range of pro-environmental solutions in the scope of implemented logistics processes, all with the support of top management. In addition, progressive companies tend to have an active, not passive, attitude to environmental challenges, thus they are not limited to complying with applicable law, but above all actively seek innovative solutions. 
In the second group, the authors indicated moderate companies for which environmental issues are not as important as in the case of progressive companies. These enterprises are considered to be an intermediate type between progressive enterprises and so-called conservative ones, which are characterized by the fact that logistics has little impact on the issues of developing and/or implementing environmental policy. Possible actions in the field of environmental protection are taken in the event of specific problems related to complying with applicable law and are most often implemented at the lowest management levels.

Biloslavo \& Trnavcevic (2009) made a different division of enterprises, taking into account the attitudes of managers towards the implementation of environmentally friendly solutions. They distinguish: 'green companies' (companies whose purpose, activities and their own material existence are in full harmony with the natural and cultural environment, and whose employees strictly adhere to ethical principles in the field of relations and communication between themselves and with the company's stakeholders), companies that are on the way to become 'green', and others.

With reference to the presented classifications of enterprises, the literature indicates four stages of 'green logistics' development in business operations (Figure 1).

Figure 1. Stages of green logistics development in business operations

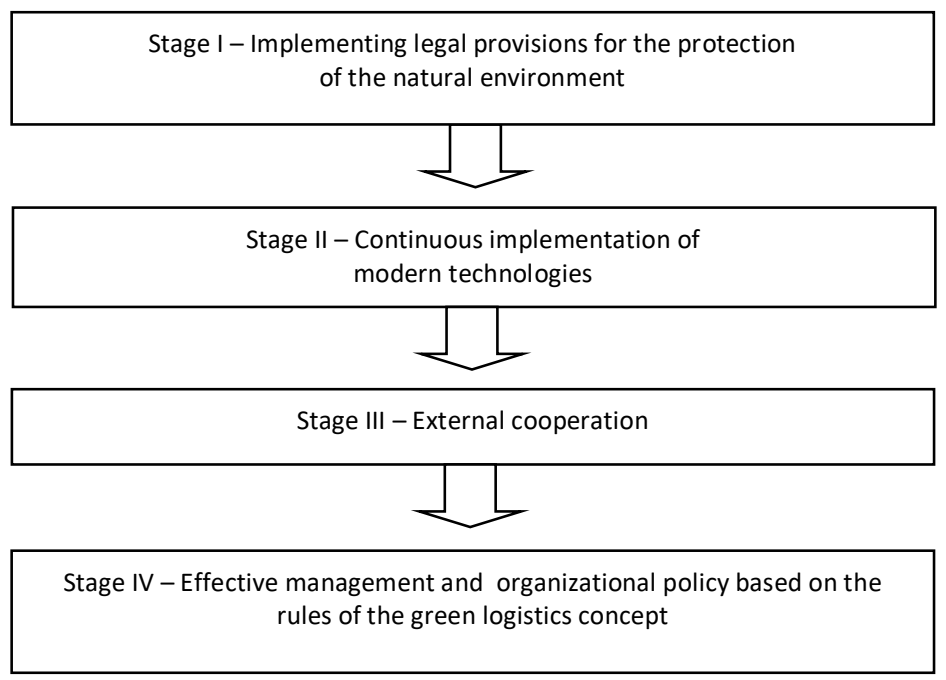

Source: Sarkis, Meade, \& Talluri (2004); Vasiliauskas, Zmkevičiüté, \& Šimonyte (2013). 
The first stage of the development of green logistics in business operations consists of implementing the legal provisions that regulate environmental issues. In this case, the actions taken by owners and managers are reactive. As a consequence, enterprises achieve a certain minimum level within the scope of the proenvironmental activities they implement. The transition to the second stage of green logistics development is conditioned by the implementation of modern technologies that meet the high requirements of environmental standards (low-emission engines, alternative drive technologies) or enable more efficient use of resources (IT systems supporting better route planning or more efficient loading). In the third stage, the need for external cooperation with other participants in the supply chain is emphasized. In practice, activities carried out in the field of logistics very often require the involvement of several companies - for example, cooperation in the fields of supply or distribution. Van Hoek (1999) emphasized that green logistics should be implemented from the perspective of the entire supply chain, not a single enterprise. For example, decisions about the selection of packaging will determine not only how to organize transport and storage processes for all participants in the supply chain, but also the recycling possibilities for this packaging. At the last stage of the development of enterprises' green logistics activities, the assumptions of the concept of green logistics become an integral part of the main strategy of a given enterprise. Thus, the highest level of 'greening' of a company is achieved in the implemented logistics processes area.

In the context of the enterprise classification according to the level of implementation of 'green' solutions in the area of logistics, a question should be asked about the boundaries between individual types of enterprises. For an enterprise to self-assess in terms of the degree of achieved 'green' awareness, López-Gamero, Molina-Azorín, \& Claver-Cortés (2010), and Choi \& Zhang (2011) suggest considering the following issues: awareness of the government's green policies, mindfulness of being of green mind, knowledge about being green, the behavior of staff, green standardization, green training. A different approach was proposed by Martinsen (2014). According to the guidelines provided in the paper, four elements decide about the degree of 'greening' of a given entity: the number of environmental activities; the match or gap between perceptions of supply and demand in the relationship; the type of environmental activities (simple/complex) in the relationship; the environmental ambition of the actors in the relationship. 
In the author's opinion, in addition to the criteria proposed above to distinguish 'green' enterprises from other enterprises, a certain catalogue of features of 'green' enterprises should be created that would allow those enterprises to be distinguished from the others. Based on the solutions proposed by López-Gamero et al. (2010), Choi \& Zhang (2011) and Martinsen (2014), only self-assessment is possible. Therefore, it is not possible to carry out external identification (for example, by government administration bodies or nongovernmental organizations) which makes it difficult to reach small and medium-sized enterprises interested in implementing 'green logistics'.

\section{Research methodology}

\subsection{Sample and research settings}

The study was conducted during June and July 2017 using an electronic questionnaire. Invitations to the study were sent with the support of the Research and Knowledge Transfer Centre at the University of Economics in Katowice. The respondents included representatives (owners and managers) of 200 small and medium-sized enterprises operating in Poland.

Due to financial and organizational limitations, the selection of enterprises for the sample was quota-based. Therefore, one of the best known and popular types of non-random selection was used (Sagan, 2016). This means that the size of the individual subgroups, distinguished on the basis of the selected control variables, is proportional to their size in the general population. In other words, the structure of the general population of small and medium-sized enterprises operating in Poland was reflected in the studied group of enterprises. Consequently, taking into account two variables, the level of employment (expressed by the number of people employed) and the dominant type of business activity according to the PKD (Polish Classification of Businesses), the research was conducted with a group of 157 small and 43 medium-sized enterprises.

To achieve the presupposed aim of the paper, the classification tree method (Breiman, Friedman, Olshen, \& Stone, 1984) was used with the support of R statistical software. 


\subsection{Variable measurement}

In order to distinguish 'green' enterprises from other enterprises, the author used the classification tree method, described for the first time by Breiman, Friedman, Olshen, \& Stone (1984), which consists of dividing the set of examined objects into homogeneous classes. As a result, a set of classification rules is obtained, which allows the examined objects to be assigned to a particular class. In the case of the author's research, the surveyed enterprises were divided into 'green' and 'other'. The 'green' enterprises included those enterprises which were in the fourth stage of the development of 'green logistics' The 'other' enterprises included enterprises which were in the first, second or third stages of the development of 'green logistics'. The division of the surveyed enterprises into two classes is presented in Figure 2. In the group of features describing the distinguished classes, the metric characteristics of the surveyed enterprises were used (employment size, amount of net annual turnover, capital relations, type of business, operating range, position in the supply chain) (Carbone \& Moatti, 2012; Fura \& Surmacz, 2014; Glover, Champion, Daniels, \& Dainty, 2014; Holt, 2004; Kumar \& Chandrakar, 2012; Min \& Galle, 2001; Rao, 2007; Xu, Mathiyazhagan, Govindan, Haq, Ramachandran, \& Ashokkumar, 2013; Zhu \& Sarkis, 2006) - Table 1.

Figure 2. Classification of the surveyed enterprises ('green' and 'other')

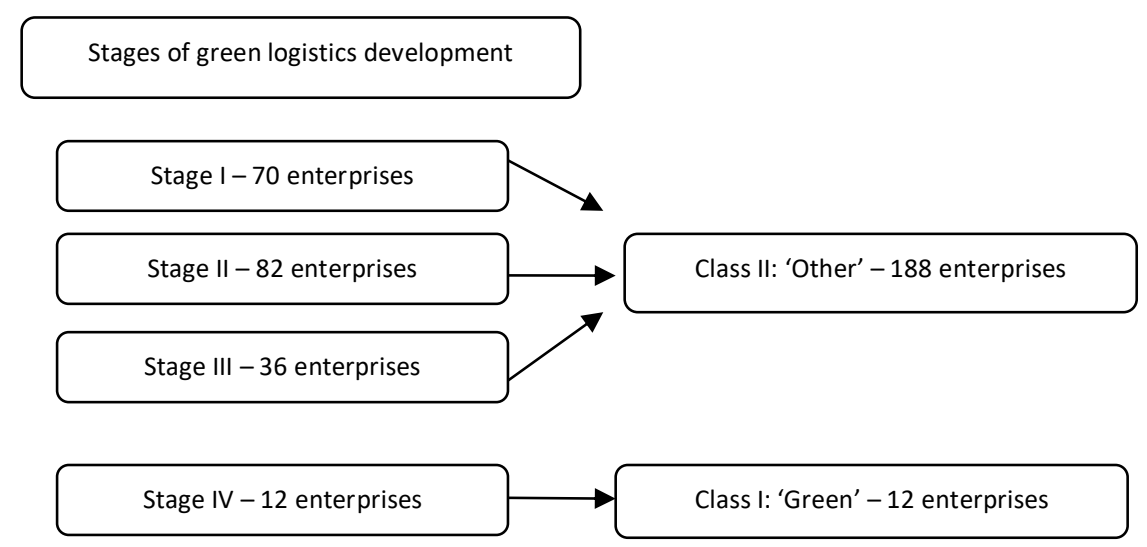

Source: Author's own research. 
Table 1. The set of features used for classification-trees analysis

\begin{tabular}{|c|c|c|c|}
\hline \multicolumn{4}{|c|}{ Question number, criterion } \\
\hline \multicolumn{2}{|c|}{ Q1. Employment } & Yes & No \\
\hline 1.1 & 10-49 employees & 1 & 2 \\
\hline 1.2 & 50-249 employees & 1 & 2 \\
\hline \multicolumn{4}{|c|}{ Q2. Annual net turnover [EUR] } \\
\hline 2.1 & $<0-2 \mathrm{~m}>$ & & \\
\hline 2.2 & $<2-10 \mathrm{~m}>$ & & \\
\hline 2.3 & $<10-50 \mathrm{~m}\rangle$ & & \\
\hline 2.4 & $50 \mathrm{~m}$ and more & & \\
\hline \multicolumn{4}{|c|}{ Q3. Capital relations } \\
\hline 3.1 & Our company is capital-independent from other entities & & \\
\hline 3.2 & Our company is capital-related with other entities at less than $25 \%$ & & \\
\hline 3.3 & Our company is capital-related with other entities from $25 \%$ to $50 \%$ & & \\
\hline 3.4 & Our company's capital relations with other entities are above $50 \%$ & & \\
\hline \multicolumn{2}{|r|}{ Q4. Type of business according to the PKD } & Yes & No \\
\hline 4.1 & Production & 1 & 2 \\
\hline 4.2 & Construction & 1 & 2 \\
\hline 4.3 & Trade & 1 & 2 \\
\hline 4.4 & TFL (Transport Forwarding Logistics) & 1 & 2 \\
\hline 4.5 & Other services & 1 & 2 \\
\hline \multicolumn{4}{|c|}{ Q5. Operating range } \\
\hline 5.1 & Local & & \\
\hline 5.2 & Regional & & \\
\hline 5.3 & National & & \\
\hline 5.4 & International & & \\
\hline 5.5 & Global & & \\
\hline \multicolumn{2}{|c|}{ Q6. Position in the supply chain } & Yes & No \\
\hline 6.1 & Indirect supplier of supply chain leader & 1 & 2 \\
\hline 6.2 & Direct supplier of supply chain leader & 1 & 2 \\
\hline 6.3 & Supply chain leader & 1 & 2 \\
\hline 6.4 & Direct customer of supply chain leader & 1 & 2 \\
\hline 6.5 & Indirect customer of supply chain leader & 1 & 2 \\
\hline \multicolumn{2}{|r|}{ Q7. Implemented ISO 14001} & Yes & No \\
\hline 7 & ISO 14001 & 1 & 2 \\
\hline \multicolumn{2}{|c|}{ Q8. Implemented CSR } & Yes & No \\
\hline 8 & CSR & 1 & 2 \\
\hline \multicolumn{2}{|c|}{ Q9. Implemented ISO 26000} & Yes & No \\
\hline 9 & ISO 26000 & 1 & 2 \\
\hline
\end{tabular}

Source: Author's own research. 


\section{Research findings and discussion}

The classification tree resulting from the modelling carried out, taking into account the metric characteristics of the surveyed enterprises, is presented in Figure 3.

Figure 3. The classification tree model

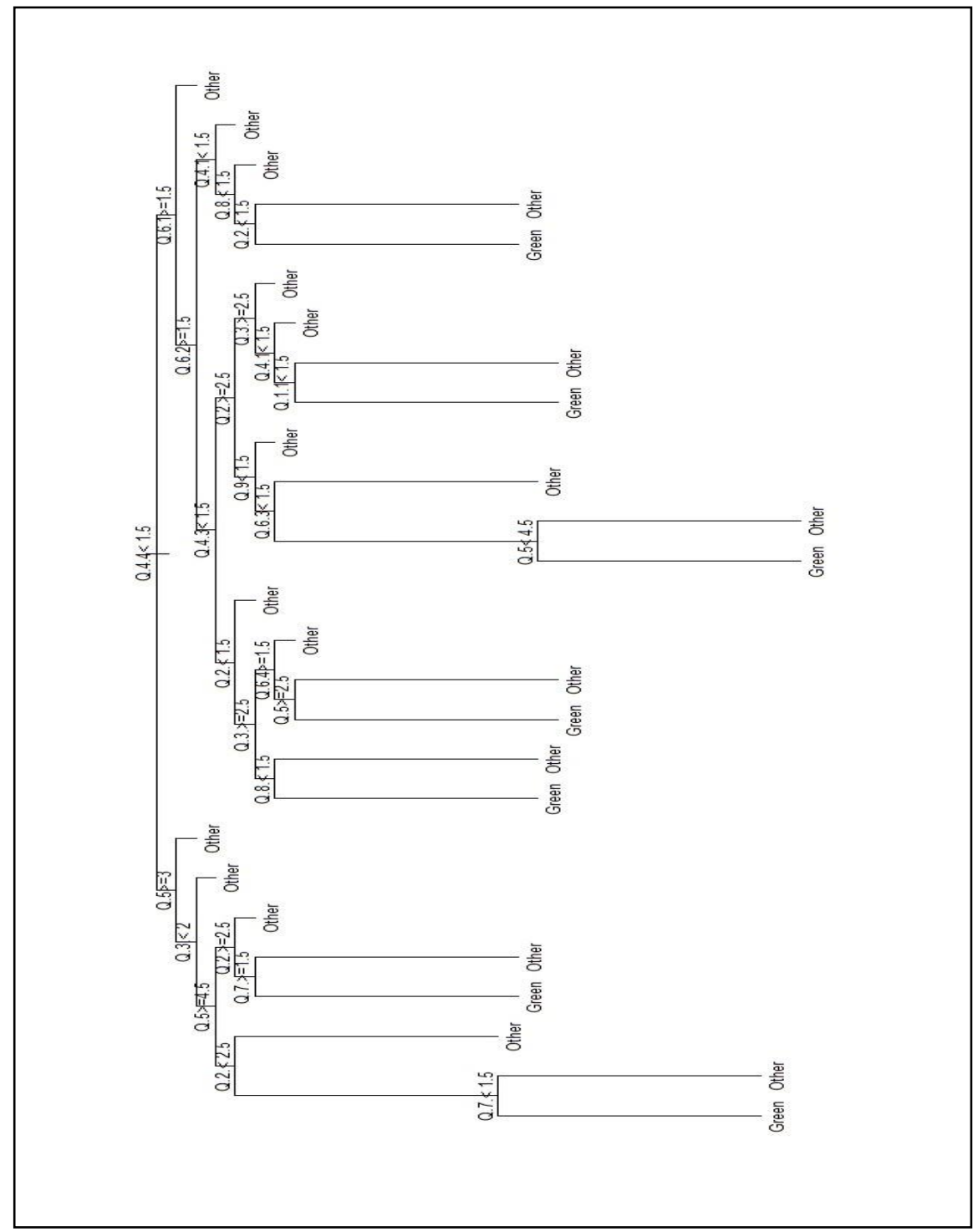

Source: Author's own research. 
The classification tree model shows a very good fit to the data. The classification error of this model was only $1.5 \%$, which means that the classification rules correctly identify the class membership of $98.5 \%$ of the surveyed enterprises (other classification quality measures: sensitivity $=75 \%$; precision $=$ $=100 \% ; \mathrm{F} 1=85.7 \% ; \mathrm{AUC}=87.5 \%)$. A more detailed analysis showed that all 'other' enterprises and nine green enterprises were classified correctly (this means that three 'green' enterprises were incorrectly classified). The graphical form of the model shows that seven rules for enterprises to belong to the 'green' class (Table 2) and 20 rules for enterprises to belong to the 'other' class were identified.

Table 2. The rules for enterprises to belong to the 'green' class

\begin{tabular}{|c|c|l|}
\hline $\begin{array}{c}\text { Rule } \\
\text { number }\end{array}$ & $\begin{array}{c}\text { Number } \\
\text { of enter- } \\
\text { prises }\end{array}$ & \multicolumn{1}{|c|}{ Enterprise characteristics } \\
\hline 1 & 2 & $\begin{array}{l}\text { A company from the TFL sector with a global range, capital-independent, } \\
\text { with an annual net turnover of max. EUR 10 million, having ISO 14001 }\end{array}$ \\
\hline 2 & 1 & $\begin{array}{l}\text { A company from the TFL sector with an international range, capital-independent, } \\
\text { with an annual net turnover more than EUR 10 million, not having ISO 14001 }\end{array}$ \\
\hline 3 & 1 & $\begin{array}{l}\text { A trading company, not a direct or indirect supplier of the supply chain leader } \\
\text { (direct customer of supply chain leader), having an annual net turnover not } \\
\text { exceeding EUR 2 million, capital-related with other entities by at least 25\% } \\
\text { and having implemented CSR }\end{array}$ \\
\hline 4 & 1 & $\begin{array}{l}\text { A trading company with at least national range, not being an indirect or direct } \\
\text { supplier and customer of the supply chain leader, with an annual net turnover not } \\
\text { exceeding EUR 2 million, capital-related with other entities at most 25\% }\end{array}$ \\
\hline 5 & 2 & $\begin{array}{l}\text { A non-commercial enterprise, not belonging to the TFL sector, with an interna- } \\
\text { tional range, a supply chain leader with an annual net turnover above EUR 10 } \\
\text { million, having implemented ISO 26000 }\end{array}$ \\
\hline 7 & 1 & $\begin{array}{l}\text { A small production company, neither an indirect nor direct supplier of the supply } \\
\text { chain leader (acting as the customer of the leader) with an annual net turnover of } \\
\text { at most EUR 10 million, capital-related with other entities by at least 25\% }\end{array}$ \\
\hline $\begin{array}{l}\text { A production company that is a direct supplier of the supply chain leader, having } \\
\text { implemented CSR, with an annual net turnover of at most EUR 2 million }\end{array}$ \\
\hline
\end{tabular}

Source: Author's own research.

The conducted research showed that by identifying 'green' small and medium-sized enterprises operating in Poland, such features as belonging to the TFL (Transport Forwarding Logistics) sector and a direct relationship with the supply chain leader are important. The results obtained are in line with the research results of other authors that indicated the type of business (Carbone, Moatti, \& Wood, 2012; Rao, 2007; Xu et al., 2013; Zhu \& Sarkis, 2006) and the 
role of the enterprise in the supply chain (Glover et al., 2014, Holt, 2004; Kumar \& Chandrakar, 2012; Min \& Galle, 2001) as variables that can differentiate the scope of implementation of 'green' solutions in business operations.

In the case of enterprises from the TFL sector, their area of activity is a natural environment for the development of 'green logistics' practices (Isaksson, 2012; Isaksson \& Huge-Brodin, 2013; Isaksson, Björklund, Evangelista, \& Huge-Brodin, 2011; Martinsen \& Huge-Brodin, 2010; Weijers, Glöckner, \& Pieters, 2012; Zowada, 2019). In this case, we are talking not only about typically operational solutions, such as eco-driving, effective route planning, but also about strategic activities, such as replacement of the propulsion technologies used, wider use of intermodal transport, planning of logistics networks using environmental criteria. In turn, the supply chain leader usually pushes for specific solutions aimed at achieving the assumed goals. The influence of the supply chain leader is focused on solutions that take into account the specificity of a given chain and, above all, are tailored to its needs.

\section{Conclusions}

\subsection{Research contribution}

The publications referring to the development of 'green logistics' have so far focused primarily on the processes of implementation and development of 'green logistics' in large enterprises or entire supply chains. The main contribution of this research is to fill the research gap identified in the literature related to the development of 'green logistics' among small and medium-sized enterprises.

Thanks to the classification tree analysis, it was possible to identify the features of 'green' small and medium-sized enterprises operating in Poland. The conducted research showed that such features as belonging to the TFL (Transport Forwarding Logistics) sector and a direct relationship with the supply chain leader are important.

The results obtained are in line with the research results of other authors that indicated the type of business (Carbone \& Moatti, 2012; Rao, 2007; Xu et al., 2013; Zhu \& Sarkis, 2006) and the role of the enterprise in the supply chain (Glover et al., 2014; Holt, 2004; Kumar \& Chandrakar, 2012; Min \& Galle, 2001) as variables that can differentiate the scope of implementation of 'green' solutions in business operations. Moreover, according to the author's research, in 
the case of small and medium-sized enterprises it is worth to emphasize the role of a supply chain leader, which becomes a strong motor for implementing the 'green' solutions in the area of logistics in the small and medium-sized enterprises on higher levels of 'green logistics' development.

\subsection{Implications for research and practice}

Apart from theoretical considerations, the paper offers some practical implications. The research results enable the identification process of small and medium-sized enterprises interested in implementing the 'green logistics' concept and, consequently, their support. For example, it is possible to indicate places where programs supporting the development of 'green logistics' in small and medium enterprises in Poland should be implemented. In that context experiences from the Italian Green Logistics Initiative Project, a joint project of government institutions and representatives of industry and universities whose goal was to increase the 'greening' of implemented logistics processes (Bruzzone, Tremori, Massei, \& Tarone, 2009) or The Mexican Green Supply Chain Program (Thiell, Zuluaga, Montañez, \& Hoof, 2011), whose objectives primarily concerned the implementation of 'green logistics' solutions in the SME sector, may be used to create such programs.

\subsection{Research limitations and future research}

Limitations in the study are primarily related to the extent of research. Research results concern small and medium-sized enterprises operating in Poland and cannot be generalized to other countries. However, the conducted research may be a starting point for comparative analyses on an international scale.

The research may be the starting point for further research into the development of 'green logistics' in small and medium-sized enterprises operating in Poland or provide a basis for undertaking research in a broader context of the concept of 'sustainable logistics' or a 'sustainable supply chain'. 


\section{References}

Abdullah, M. I., Sarfraz, M., Qun, W., \& Javaid, N. (2018). Drivers of green supply chain management. LogForum, 14(4), 437-447. https://doi.org/10.17270/J.LOG. 2018.297

Ambec, S., \& Lanoie, P. (2008). Does it pay to be green? A systematic overview. Academy of Management Perspectives, 22(4), 45-62. https://doi.org/10.5465/amp.2008. 35590353

Biloslavo, R., \& Trnavcevic, A. (2009). Web sites as tools of communication of a "green" company. Management Decision, 47(7), 1158-1173. https://doi.org/ $10.1108 / 00251740910978359$

Breiman, L., Friedman, J. H., Olshen, R. A., \& Stone, C. J. (1984). Classification and regression trees. New York: Chapman \& Hall.

Bruzzone, A. G., Tremori, A., Massei, M., \& Tarone, F. (2009). Modeling green logistics. Proceedings of the Third Asia International Conference on Modelling \& Simulation (pp. 543-548). Warsaw: IEEE. https://doi.org/10.1109/AMS.2009.97

Carbone, V., Moatti, V., \& Wood, C. H. (2012). Diffusion of sustainable supply chain management: Toward a conceptual framework. Supply Chain Forum an International Journal, 13(4), 26-39. https://doi.org/10.1080/16258312.2012.11517304

Chang, Q., \& Qin, R. (2008). Analysis on development path of Tianjin green logistics. International Journal of Business and Management, 3(9), 96-98. https://doi.org/ 10.5539/ijbm.v3n9p96

Choi, Y., \& Zhang, N. (2011). Does proactive green logistics management improve business performance? A case of Chinese logistics enterprises. African Journal of Business Management, 5(17), 7564-7574. https://doi.org/10.5897/AJBM11.613

Chunguang, Q., Xiaojuan, C., Kexi, W., \& Pan, P. (2008). Research on green logistics and sustainable development. In Proceedings of the International Conference on Information Management, Innovation Management and Industrial Engineering, Taipen, Taiwan (pp. 162-165). New York: IEEE. https://doi.org/10.1109/ICIII.2008.114

Dogaru, L. (2013). The importance of environmental protection and sustainable development. Procedia - Social and Behavioral Sciences, 93, 1344-1348. https://doi.org/ 10.1016/j.sbspro.2013.10.041

European Commission. (2020). Environment action programme to 2030. Retrieved from https://ec.europa.eu/environment/strategy/environment-action-programme-2030_en

Fura, B., \& Surmacz, T. (2014). Zarządzanie środowiskowe w przedsiębiorstwach jako narzędzie służące budowie zielonych łańcuchów dostaw [Environment management in enterprises as a tool aimed at Green Supply Chain building]. Logistyka, 6, 13265-13270.

Greenpeace International. (2020). Annual report 2019. Retrieved from https://www. greenpeace.org/international/publication/43852/annual-report-2019/ 
Glover, J. L., Champion, D., Daniels, K. J., \& Dainty, A. J. D. (2014). An institutional theory perspective on sustainable practices across the dairy supply chain. International Journal of Production Economics, 152, 102-111. https://doi.org/10.1016/ j.ijpe.2013.12.027

van Hoek, R. I. (1999). From reversed logistics to green supply chains. Supply Chain Management: An International Journal, 4(3), 129-135. https://doi.org/10.1108/ 13598549910279576

Holt, D. (2004). Managing the interface between suppliers and organizations for environmental responsibility - an exploration of current practices in the UK. Corporate Social Responsibility and Environmental Management, 11(2), 71-84. https://doi. org/10.1002/csr.55

Hove-Sibanda, P., Sibanda, K., \& Mukarumbwa, P. (2018). Greening up in logistics: Managerial perceptions of small and medium-sized enterprises on sustainability in Zimbabwe. The Journal for Transdisciplinary Research in Southern Africa, 14(1), 1-13. https://doi.org/10.4102/td.v14i1.559

Isaksson, K. (2012). Logistics Service Providers going green-insights from the Swedish market (Dissertation, Linköping University). Retrieved from https://www.divaportal.org/smash/get/diva2:479727/FULLTEXT01.pdf1518

Isaksson, K., Björklund, M., Evangelista, P., \& Huge-Brodin, M. (2011). The challenge and adoption of green initiatives for transport and logistics service providers. Proceedings of the 16th Annual LRN Conference, 1-10. Retrieved from https://www. diva-portal.org/smash/get/diva2:476094/FULLTEXT01.pdf

Isaksson, K., \& Huge-Brodin, M. (2013). Understanding efficiencies behind logistics service providers' green offerings. Management Research Review, 36(3), 216-238. https://doi.org/10.1108/01409171311306382

Ivanova, T. (2020). Management of green procurement in small and medium-sized manufacturing enterprises in developing economies. Amfiteatru Economic, 22(53), 121136. https://doi.org/10.24818/EA/2020/53/121

Jabbour, A. B., Jabbour, C., Govindan, K., Kannan, D., \& Fernandes Arantes, A. (2014). Mixed methodology to analyze the relationship between maturity of environmental management and the adoption of green supply chain management in Brazil. Resources, Conservation and Recycling, 92, 255-267. https://doi.org/10.1016/j.resconrec. 2014.02.004

Jedliński, M. (2010). Między ekologią a ekonomią szkic problematyki zielonej logistyki [Between ecology and economics - draft of issues of the green logistics]. In J. Szołtysek, M. Jedliński (Eds.), Logistyka współczesne wyzwania [The contemporary challenges of logistics] (pp. 29-43). Wałbrzych: Wydawnictwo Uczelniane PWSZ im. Angelusa Silesiusa.

Kumar, R., \& Chandrakar, R. (2012). Overview of green supply chain management: Operation and environmental impact at different stages of the supply chain. International Journal of Engineering and Advanced Technology, 1(3), 1-6. Retrieved from https:// www.semanticscholar.org/paper/Overview-of-Green-Supply-Chain-Management\%3A -and-at-Kumar-Chandrakar/b96c9067e8e20bbf5a66380139409b35511fba72 
Lai, K., \& Wong, C. W. Y. (2012). Green logistics management and performance: Some empirical evidence from Chinese manufacturing exporters. Omega, 40(3), 267-282. https://doi.org/10.1016/j.omega.2011.07.002

Lau, K. H. (2011). Benchmarking green logistics performance with a composite index. Benchmarking: An International Journal, 18(6), 873-896. https://doi.org/10.1108/ 14635771111180743

Lo, S. M. (2014). Effects of supply chain position on the motivation and practices of firms going green. International Journal of Operations \& Production Management, 34(1), 93-114. https://doi.org/10.1108/IJOPM-04-2012-0133

López-Gamero, M. D., Molina-Azorín, J. F., \& Claver-Cortés, E. (2010, July). The potential of environmental regulation to change managerial perception, environmental management, competitiveness, and financial performance. Journal of Cleaner Production, 18(10/11), 963-974. https://doi.org/10.1016/j.jclepro.2010.02.015

Mala, D., \& Musova, Z. (2015). Perception of implementation processes of green logistics in SMEs in Slovakia. Procedia Economics and Finance, 26, 139-143. https://doi.org/10.1016/S2212-5671(15)00900-4

Martinsen, U. (2014). Towards greener supply chains - inclusion of environmental activities in relationships between logistics service providers and shippers (Dissertation, Linköping University). Retrieved from http://liu.diva-portal.org/smash/get/ diva2:679084/FULLTEXT01.pdf

Martinsen U., \& Huge-Brodin M. (2010). Greening the offerings of logistics service providers. Proceedings of the 22th Annual NOFOMA conference Logistics and Supply Chain Management in a Globalised Economy, 969-984.

McKinnon, A., Browne, M., Piecyk, M., \& Whiteing, A. (Eds.). (2015). Green logistics: Improving the environmental sustainability of logistics (3rd ed.). London: Kogan Page.

Min, H., \& Galle, W. P. (2001). Green purchasing practices of US firms. International Journal of Operations \& Production Management, 21(9), 1222-1238. https://doi. org/10.1108/EUM0000000005923

Murphy, P. R., Poist, R. F., \& Braunschweig, Ch. D. (1995). Role and relevance of logistics to corporate environmentalism: An empirical assessment. International Journal of Physical Distribution \& Logistics Management, 25(2), 5-19. https://doi. org/10.1108/09600039510083916

Rao, P. (2007). Greening of the supply chain: An empirical study for SMES in the Philippine context. Journal of Asia Business Studies, 1(2), 55-66. https://doi.org/ $10.1108 / 15587890780001296$

Sagan, A. (2016). Metodologia badań ekonomicznych [Methodology of economic research]. Kraków: Wydawnictwo Uniwersytetu Ekonomicznego w Krakowie.

Sarkis, J. (2012). A boundaries and flows perspective of green supply chain management. Supply Chain Management: An International Journal, 17(2), 202-216. https://doi.org/10.1108/13598541211212924 
Sarkis, J., Meade, L. M., \& Talluri, S. (2004). E-logistics and the natural environment. Supply Chain Management. An International Journal, 9(4), 310-311. https://doi. org/10.1108/13598540410550055

Tamulis, V., Guzavičius, A., \& Žalgiryte, L. (2012). Factors influencing the use of green logistics: Theoretical implications. Economics and Management, 17(2), 706-711. https://doi.org/10.5755/j01.em.17.2.2202

Testa, F., \& Iraldo, F. (2010, July). Shadows and lights of GSCM (Green Supply Chain Management): Determinants and effects of these practices based on a multinational study. Journal of Cleaner Production, 18(10-11), 953-962. https://doi.org/ 10.1016/j.jclepro.2010.03.005

Thiell, M., Zuluaga, J. P. S., Montañez, J. P. M., \& Hoof, B. (2011). Green logistics: Global practices and their implementation in emerging markets. In Z. Luo (Eds.), Green Finance and Sustainability: Environmentally-Aware Business Models and Technologies (pp. 334-357). Hershey, PA: IGI Global. https://doi.org/10.4018/978$1-60960-531-5$

Vachon, S., \& Klassen, R. D. (2007). Supply chain management and environmental technologies: The role of integration. International Journal of Production Research, 45, 401-423. https://doi.org/10.1080/00207540600597781

Vasiliauskas, A. V., Zmkevičiüté, V., \& Šimonyte, E. (2013). Implementation of the concept of green logistics reffering (sic!) to IT applications for road freight transport enterprises. Business: Theory and Practice, 14(1), 43-50. https://doi.org/ 10.3646/btp.2013.05

UN. (2020). Crafting a new relationship between people and planet in 2021. Retrieved from https://www.unep.org/news-and-stories/story/crafting-new-relationship-between -people-and-planet-2021

Weijers, S., Glöckner, H. H., \& Pieters R. (2012). Logistic service providers and sustainable physical distribution. LogForum, 8(2), 157-165.

World Bank. (2020). Healthy environment, thriving economies, resilient planet. Retrieved from https://www.worldbank.org/en/topic/environment

WTO. (2020). WTO Trade and Environment Week 2020. Retrieved from https://www. wto.org/english/tratop_e/envir_e/tedweek2020_e.htm

WWF. (2020). Living Planet Report 2020. Retrieved from https://livingplanet.panda.org/

Xu, L., Mathiyazhagan, K., Govindan, K., Haq, A.N., Ramachandran, N.V., \& Ashokkumar, A. (2013). Multiple comparative studies of Green Supply Chain Management: Pressures analysis. Resources, Conservation and Recycling, 78, 26-35. https://doi.org/10.1016/j.resconrec.2013.05.005

Zhang, Y., Thompson, R. G., Bao, X., \& Jiang, Y. (2014). Analyzing the promoting factors for adopting green logistics practices: A case study of road freight industry in Nanjing, China. Procedia - Social and Behavioral Sciences, 125, 432-444. https://doi.org/10.1016/j.sbspro.2014.01.1486 
Zhu, Q., \& Sarkis, J. (2006). An inter-sectoral comparison of green supply chain management in China: Drivers and practices. Journal of Cleaner Production, 14(5), 472-486. https://doi.org/10.1016/j.jclepro.2005.01.003

Zowada, K. (2019). Rynek TSL jako płaszczyzna rozwoju zielonych praktyk logistycznych [The TSL market as an area of the development of green logistics practices]. Marketing $i$ Rynek, 12, 80-85. https://doi.org/10.33226/1231-7853. 2019.12.14

Zowada, K. (2020). Green logistics: The way to environmental sustainability of logistics. Empirical evidence from Polish SMEs. European Journal of Sustainable Development, 9(4), 231-240. https://doi.org/10.14207/ejsd.2020.v9n4p231

Zowada, K., \& Niestrój, K. (2019). Cooperation of small and medium-sized enterprises with other supply chain participants in implementing the concept of green logistics. Research Papers of Wroclaw University of Economics, 63(6), 252-253. https://doi. org/10.15611/pn.2019.6.20 